\title{
FORgOTTEN? THE ROLE OF GRADUATE LEGAL EDUCATION IN THE FUTURE OF THE LAW FACULTY
}

\author{
ROSALIE JUKIER AND KATE GLOVER*
}

In this article, the authors argue that the longstanding trend of excluding graduate studies in law from the discourse on legal education has detrimental effects on both the discourse and the future of the law faculty. More specifically, disregarding graduate legal education is at odds with the reality of graduate studies in Canadian law faculties today, ignores the challenges of graduate programs in law, and perpetuates inaccurate distinctions about both the career aspirations of law students and the relationship between undergraduate and graduate legal studies. In the authors' view, these concerns can be overcome by reframing the discourse. Once the purpose of legal education is understood to be the cultivation of jurists and the law faculty is seen as an integrated whole of people, place, and program, graduate legal education moves easily into the discussion on the future of the law faculty. Including graduate studies in the discourse is an opportunity to explore, and be hopeful about, the institutional missions of law faculties and their place in the university, the optimization of legal education at all levels, and the methods by which participants in graduate studies should fulfill their responsibilities to the future of the discipline.
Les auteurs de cet article font valoir que la longue tendance d'exclure les études supérieures en droit du discours sur l'éducation juridique a des effets néfastes sur, à la fois, le discours et l'avenir de la faculté de droit. Tout particulièrement, le fait de ne pas tenir compte de l'éducation juridique supérieure ne correspond pas à la réalité des programmes d'études supérieures des écoles de droit canadiennes d'aujourd'hui; il ignore les problèmes des programmes d'études supérieures en droit et perpétue les mauvaises distinctions entre à la fois les aspirations professionnelles des étudiants en droit et la relation entre les études de premier cycle et les études supérieures. L'auteur est d'avis qu'il est possible de surmonter des inquiétudes en recadrant le débat. Une fois que l'on comprend que l'éducation juridique consiste en la culture de juristes et que la faculté de droit est considérée comme un ensemble intégré de gens, de lieux et de programmes, les études supérieures s'intègrent alors facilement dans le débat sur l'avenir de la faculté de droit. Le fait d'inclure les études supérieures dans ce débat représente une possibilité à explorer et qu'il faut espérer pour les missions institutionnelles des facultés de droit et leur place dans l'université, l'optimisation de l'éducation juridique à tous les niveaux et les méthodes au moyen desquelles les participants aux études supérieures doivent assumer leurs responsabilités à l'égard de l'avenir de leur discipline.

\section{TABLE OF CONTENTS}

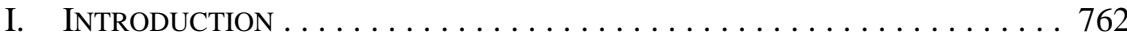

II. THE EXISTING DisCOURSE:

WHERE IS GRAdUATE LEGAL EdUCATION? . . . . . . . . . . . . . . . . . 763

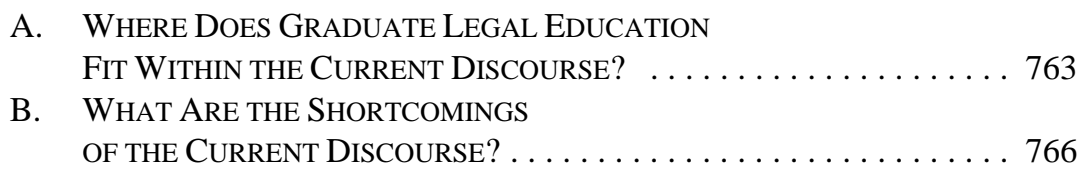

Rosalie Jukier, Professor, Faculty of Law, McGill University and member of its Paul-André Crépeau Centre for Private and Comparative Law. She served as Associate Dean, Graduate Studies, at McGill's Faculty of Law from 2010 to 2013. Kate Glover, doctoral candidate, Faculty of Law, McGill University and Vanier Canada Graduate Scholar (2012-2015). This article is a fully co-authored work - the order of authors is not indicative of unequal input. We thank Professor Angela Campbell and doctoral candidates Blair Major and Kuzi Charamba for their insightful comments on earlier versions of this article. We are also grateful for the many comments and questions we received from the attendees of The Future of Law School Conference, University of Alberta, 26-28 September 2013, for which this article was originally prepared. 
C. How Can We Overcome These Shortcomings? . . . . . . . . . 770

III. THE FUTURE DisCOURSE:

LESSONS FOR THE LAW FACULTY . . . . . . . . . . . . . . . . . . . . . . 772

A. The Impact Of Graduate StUdies on A LaW Faculty's

MisSION AND PlACE IN THE UNIVERSITY $\ldots \ldots \ldots \ldots \ldots \ldots \ldots 72$

B. THE IMPACT OF THINKING OF A LAW FACULTY

AS AN INTEGRATED WHOLE . . . . . . . . . . . . . . . . 776

C. THE IMPACT OF TODAY'S

DOCTORAL EDUCATION ON TOMORROW's LAW FACULTY $\ldots \ldots \ldots 780$

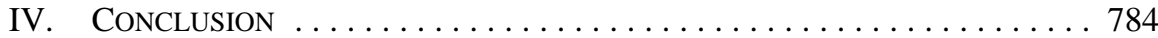

\section{INTRODUCTION}

The future of the law faculty is in flux. Many say it is in crisis. The conversation about the crises and their possible solutions is animated and multifaceted, but also incomplete. In this article, we focus on one aspect of legal education that has been habitually forgotten from the discussion — graduate studies in law. In Part II, we uncover some implications of excluding graduate legal education from the discourse. In Part III, we reveal some effects of its inclusion on the future of the law faculty. Ultimately, we contend that bringing graduate legal education into the discussion provides valuable lessons about a faculty's mission, pedagogy, and culture, as well as its responsibility to cultivate the leaders of tomorrow's law faculties.

As co-authors, we approach the issues in this article from different perspectives. One of us is a law professor and a former associate dean of graduate studies; the other is a doctoral student and an aspiring law professor. This article is the product of an ongoing dialogue between us in which, while we often agreed, we have consistently challenged each other's views. From the outset, we have shared a common starting point: the realization that graduate legal education is largely absent from the discourse about the crises and future of legal education and that this absence does not accord with our understanding and experience of graduate studies within the law faculty. Our differing perspectives have enriched our inquiry into the implications of this starting point. At a minimum, they have informed our dual focus, namely an interest in graduate legal education both in and of itself, and as a lens through which to examine the future of the law faculty ${ }^{1}$ and undergraduate programs in law. ${ }^{2}$

While this article focuses on legal education in university-based law faculties, we believe that legal education occurs both inside and outside the law faculty, formally and informally, in a variety of sites and through a variety of media. See e.g. Roderick A Macdonald, "Everyday Lessons of Law Teaching — Le quotidien de l'enseignement juridique” (2012) 6 CLEAR 1 [Macdonald, “Everyday Lessons”]; Roderick A Macdonald \& Kate Glover, "Implicit Comparative Law” (2013) 43: 1 \& 2 RDUS 123; Desmond Manderson \& Sarah Turner, "Coffee House: Habitus and Performance Among Law Students" (2006) 31:3 Law \& Social Inquiry 649. However, in this article, we focus our inquiry on law faculties because they are the sites in which the distinction between "graduate" and "undergraduate" studies is most easily available. Moreover, it is appropriate given that we aim to incite further examination of the role of graduate studies in the future of the law faculty.

We use the term “undergraduate legal education” to signify first-level, or premier cycle, university-based legal education programs that lead to a degree of LLB, BCL, LLL or JD. In contrast, we use "graduate legal education" or "graduate studies in law" to refer to second and third level, or deuxième et troisième cycle, university-based legal education programs that lead to master's and doctoral degrees in law such as an LLM, DCL, LLD, PhD, SJD, and JSD. 


\section{THE EXISTING Discourse: WHERE IS GRADUATE LEGAL EDUCATION?}

In this Part, we consider the role that has been assigned to graduate studies in the ongoing conversation about the future of legal education and assess the merits of that role. We ask three questions. First, where does graduate legal education fit within the current discourse? Second, what are the shortcomings of that discourse? Third, how do we move beyond these shortcomings? We contend that graduate legal education is marginalized in the discourse and that this raises a number of concerns about the accuracy and adequacy of forecasts and recommendations for the future. In response to this observation, we offer one way to reframe the conversation in an effort to alleviate the concerns and bring graduate legal studies constructively into the discourse.

\section{A. Where Does Graduate Legal Education Fit WiTHIN THE CURRENT DisCoURSE?}

A dominant narrative in the discourse is that North American legal education is plagued by crisis and that law faculties face a litany of challenges as they move into the future. Although the extent and experience of the crises differ in some respects in Canada and the United States, many of the same pressures weigh on law faculties in both jurisdictions. ${ }^{3}$ Some commentators claim that law faculties fail because their graduates are not adequately prepared in the skills and formative values necessary for legal practice. ${ }^{4}$ Relatedly, it is also

3 The discourse on legal education takes place not only within the legal community, but also in the media. In the Canadian print media, see e.g. Sarah Rankin, "Today’s law grad: Six figures in debt and heading to Bay Street," The Globe and Mail (2 April 2013), online: The Globe and Mail <http://www.the globeandmail.com/news/national/education/todays-law-grad-six-figures-in-debt-and-heading-to-baystreet/article10565699/>; Mary Teresa Bitti, “Legal Jobs: Time to retool legal education,” Financial Post (1 February 2012), online: Financial Post <http://business.financialpost.com/2012/02/01/legal-jobs-timeto-retool-legal-education/>; Bruce Feldthusen, "Legal profession in turmoil: Let's blame the law schools," Canadian Lawyer Magazine (3 December 2012), online: Canadian Lawyer Magazine <http:// www.canadianlawyermag.com/4429/Legal-profession-in-turmoil-Lets-blame-the-law-schools.html>; Jan Weir, "Law schools are the cause of the articling crisis," Canadian Lawyer Magazine (14 January 2013), online: Canadian Lawyer Magazine < http://www.canadianlawyermag.com/4471/Law-schoolsare-the-cause-of-the-articling-crisis.html>. In the American print media, see e.g. Ethan Bronner, “A Call for Drastic Changes in Educating New Lawyers,” The New York Times (10 February 2013), online: The New York Times <http://www.nytimes.com/2013/02/11/us/lawyers-call-for-drastic-change-in-educating -new-lawyers.html>; David Segal, “What They Don't Teach Law Students: Lawyering,” The New York Times (19 November 2011), online: The New York Times <http://www.nytimes.com/2011/11/20/ business/after-law-school-associates-learn-to-be-lawyers.html>; Lincoln Caplan, “An Existential Crisis for Law Schools,” The New York Times (14 July 2012), online: The New York Times < http://www.ny times.com/2012/07/15/opinion/sunday/an-existential-crisis-for-law-schools.html>; "The Case Against Law School,” The New York Times (21 July 2011), online: The New York Times <http://www.ny times.com/roomfordebate/2011/07/21/the-case-against-law-school $>$. For some comparative discussion, see e.g. Lorne Sossin, “Do Canadian Law Schools Face an Existential Crisis?” Dean Sossin's Blog (23 July 2012), online: Osgoode Hall Law School < http://deansblog.osgoode.yorku.ca/2012/07/do-canadianlaw-schools-face-an-existential-crisis/> [Sossin, "Existential”]; Matt LaForge, "The lawyer job market for young lawyers in Canada,” The Lawyers Weekly (23 September 2011), online: The Lawyers Weekly <http://www.lawyersweekly.ca/index.php? section=article\&articleid=1499>.

$4 \quad$ See e.g. ibid. In Canada, see also Articling Task Force, Final Report, October 25, 2012: Pathways to the Profession: A Roadmap for the Reform of Lawyer Licensing in Ontario (The Law Society of Upper Canada, 2012), online: The Law Society of Upper Canada <http://lsuc.on.ca/WorkArea/Down loadAsset.aspx?id=2147489848 > [LSUC Report]; Task Force on the Canadian Common Law Degree, Final Report, October 2009 (Federation of Law Societies of Canada, 2009) [Federation Report]. In the United States, see e.g. Brian Z Tamanaha, Failing Law Schools (Chicago: University of Chicago Press, 2012) [Tamanaha, Failing]; William M Sullivan et al, Educating Lawyers: Preparation for the Profession of Law (San Francisco: Jossey-Bass, 2007) [Carnegie Report]; Task Force on the Future of Legal Education, Working Paper, 1 August 2013 (American Bar Association, 2013), online: American Bar Association <http://www.americanbar.org/content/dam/aba/administrative/professional_respons ibility/taskforcecomments/aba_task_force_working_paper_august_2013.authcheckdam.pdf>. 
claimed that law professors are overpaid, under-producing, “chin-stroking” academics with no experience in legal practice and an inability to teach law students what they expect or need to learn. ${ }^{5}$ Others point to the high, and sometimes unsustainable, debt of law students in a climate of insufficient employment opportunities, ${ }^{6}$ as well as to the experience of law faculties, which must strive to meet increased demands within the constraints of a neo-liberal political economy and reduced resources. ${ }^{7}$ Others challenge law faculties' understanding of their constituencies, arguing that institutional complacency, uncertainty about the needs of those they serve, and failure to respond to pressures on the conditions of work in law faculties will be the downfall of legal education. ${ }^{8}$ On this view, law faculties must evolve in accordance with individual, institutional, and systemic needs in order to survive, let alone thrive.

Critics across North America propose ways in which law faculties can overcome these crises. Proposals habitually suggest that law faculties strengthen their relationships to the legal profession and its regulators. Recommendations often call for curricular and programmatic change, such as reducing the time of completion from three years to two and substituting one year of law classes with apprenticeship. ${ }^{9}$ Other commentators argue that law professors should, at a minimum, have a legal education and experience as a practicing

Anthony T Kronman, The Lost Lawyer: Failing Ideals of the Legal Profession (Cambridge: Harvard University Press, 1993); Tamanaha, Failing, ibid; Segal, supra note 3.

$6 \quad$ See supra note 3; LSUC Report, supra note 4; Tamanaha, Failing, ibid at 186.

The demands on Canadian law faculties include: increasing variety in graduates' career intentions; the regulatory environment controlling access to the legal profession; ballooning core curricular content; a globalized legal profession; changing faculty expectations and aspirations; and evolving criteria measuring the quality of legal education (with respect to such things as class size, exchange opportunities, clinical programs, and moot competitions). For Canadian commentary on the experience of law faculties, see e.g. Joost Blom, "Looking Ahead in Canadian Law School Education” (1999) 33:1 UBC L Rev 7; Annie Rochette \& W Wesley Pue, “'Back to Basics”? University Legal Education and 21st Century Professionalism” (2001) 20 Windsor YB Access Just 167; Theresa Shanahan, "Legal Scholarship in Ontario’s English-speaking Common Law Schools” (2006) 21:2 CJLS 25 [Shanahan, "Scholarship"]; Theresa Shanahan, "Creeping Capitalism and Academic Culture at a Canadian Law School” (2008) 26 Windsor YB Access Just 121 [Shanahan, “Capitalism”]; Feldthusen, supra note 3; Weir, supra note 3.

$8 \quad$ See e.g. Sossin, "Existential," supra note 3; LSUC Report, supra note 4; Federation Report, supra note 4; Julian Webb, "The 'Ambitious Modesty' of Harry Arthurs' Humane Professionalism” (2006) 44:1 Osgoode Hall LJ 119; Margaret Thornton, “Among the Ruins: Law in the Neo-Liberal Academy” (2001) 20 Windsor YB Access Just 3; Harry W Arthurs, "The State We're In: Legal Education in Canada's New Political Economy" (2001) 20 Windsor YB Access Just 35; Pue \& Rochette, ibid; Shanahan, "Capitalism," ibid; Shanahan, "Scholarship," ibid; Constance Backhouse, "The Changing Landscape of Canadian Legal Education” (2001) 20 Windsor YB Access Just 25; Harry Arthurs, "The world turned upside down: are changes in political economy and legal practice transforming legal education and scholarship, or vice versa?” (2001) 8:1 Int'l J Legal Profession 11; Annie Rochette, Teaching and Learning in Canadian Legal Education: An Empirical Exploration (DCL Thesis, McGill University Faculty of Law, 2010) [unpublished]. These pressures include demands on faculty members' time, the effects of corporatized universities, the globalized, internationalized, and pluralistic environment in which law faculties operate, and changing notions of professionalism. See e.g. Harry W Arthurs, "Poor Canadian Legal Education: So Near to Wall Street, So Far From God” (2000) 38:3 Osgoode Hall LJ 381 at $402-403$.

$9 \quad$ See e.g. Tamanaha, Failing, supra note 4. See generally supra note 3. Other suggestions include designing the curriculum to reflect the Carnegie approach (Carnegie Report, supra note 4; LSUC Report, supra note 4; Federation Report, supra note 4) and implementing more experiential learning opportunities: LSUC Report, supra note 4; Jacqueline A Horvat et al, "Minority Report" in LSUC Report, supra note 4 at 70; Lorne Sossin, "Experience the Future of Legal Education" Dean Sossin's Blog (26 October 2012), online: Osgoode Hall Law School < http://deansblog.osgoode.yorku.ca/2012/10/ experience-the-future-of-legal-education/>. 
lawyer, ${ }^{10}$ and that law faculties should educate students in values, whether of the practicing bar, the legal profession writ large, or the discipline more broadly. ${ }^{11}$

This summary of the narrative of crisis, while painted in broad strokes, ${ }^{12}$ conveys the main message that legal education is in a period of destabilizing change. ${ }^{13}$ For us, it raises the question: where is graduate legal education?

The answer is that graduate programs have largely been forgotten from the discussion. ${ }^{14}$ And, to the extent they are discussed, they are usually the object of blame or the subject of criticism. First, blame. Graduate studies has been implicated by critics who lament the "academization" of undergraduate legal education. ${ }^{15}$ The critique is that law professors entrenched within the university, focused on research and scholarship, usually holding at least one graduate degree, often lacking experience in legal practice, and sometimes lacking legal training - teach their students to disdain and dilute the practical wisdom necessary for the successful practice of law. ${ }^{16}$ Commentators argue that members of faculty hiring committees hold graduate degrees and therefore expect candidates for professorial positions to be similarly credentialed. As a result, it is argued, aspiring law professors pursue graduate studies and when they become law professors, they, too, will teach law "academically," thereby perpetuating the cycle of academization. ${ }^{17}$ Additionally, faculty members increasingly expect their teaching and research to complement each other, ${ }^{18}$ thereby fuelling calls for new or expanded graduate programs, which reinforce professors' ability to advance their own research and promote the idea that the study of law is an academic endeavour. ${ }^{19}$

$10 \quad$ Kronman, supra note 5; Tamanaha, Failing, supra note 4.

11 See e.g. W Wesley Pue, “Educating the Total Jurist?” (2005) 8:2 Legal Ethics 208; Kronman, supra note 5; Tamanaha, Failing, ibid; Shauna Van Praagh, “Teaching Law: 'Historian \& Prophet All in One”” in Helge Dedek \& Shauna Van Praagh, eds, Stateless Law: Evolving Boundaries of a Discipline (Farnham, Surrey, UK: Ashgate) [forthcoming in 2014]. Additional proposals call for differentiating the market so that some law faculties design more accessible, less expensive programs: see e.g. Tamanaha, Failing, ibid; Brian Z Tamanaha, "How to Make Law School Affordable,” The New York Times (31 May 2012), online: The New York Times <http:/www.nytimes.com/2012/06/01/opinion/how-to-make-law-schoolaffordable.html >; Sossin, "Existential," supra note 3.

12 For a sample of the literature, consider some Canadian symposia on this issue over the past thirty years: see e.g. The Symposium on Canadian Legal Scholarship (1985) 23:3 Osgoode Hall LJ [special issue]; Ruth Buchanan, Marilyn MacCrimmon \& W Wesley Pue "Legal Knowledge For Our Times: Rethinking Legal Knowledge and Legal Education” (2001) 20 Windsor YB Access Just xiii; Bruce Ziff, “The Canadian Law Review Experience: Introduction to the Symposium” (2001) 39:3 Alta L Rev 611ff; Ruth Murbach, "The Arthurs Report on Law and Learning” (2003) 18:1 CJLS 1ff; Proceedings of The Second National Law Journal Conference: “Better Scholarship, Better Pedagogy, Greater Openness,” Faculty of Law, Queen's University, 29-31 October 2010, published in (2011) 36:2 Queen's LJ. In the US, see Kathleen Carrick \& Sally Walters, eds, A Bibliography of United States Legal Education: From Litchfield to Lexis (Buffalo: William S Hein), 2003. Additional collections include Fiona Cownie, ed, The Law School: Global Issues, Local Questions (Aldershot, UK: Dartmouth, 1999); Fiona Cownie, Legal Academics: Culture and Identities (Oxford: Hart, 2004); Fiona Cownie, ed, Stakeholders in the Law School (Oxford: Hart, 2010).

13 See supra note 3.

$14 \quad$ Sanjeev S Anand, “Canadian Graduate Legal Education: Past, Present and Future” (2004) 27:1 Dal LJ 55; Gail J Hupper, “The Academic Doctorate in Law: A Vehicle for Legal Transplants?” (2008) 58:3 $\mathrm{J}$ Legal Educ 413.

15 Hupper, ibid at 427-28.

16 Kronman, supra note 5 at 264-70. Kronman uses the term “antiprudentialism” to describe this approach to teaching law.

Kronman, ibid; see also supra note 3.

$18 \quad$ McGill University's Teaching and Learning Services has initiated a university-wide initiative exploring how instructors can integrate teaching with research and scholarship to benefit student learning within undergraduate courses. See "Nexus between Teaching, Learning \& Research/Scholarship,” online: McGill Teaching and Learning Services <http://www.mcgill.ca/tls/projects/nexus>. Blom, supra note 7 at 13 . 
Second, criticism. The state of North American graduate legal education has been criticized as inadequate, unnecessary, and misdirected. With respect to the American experience, Professor Tamanaha, for example, contends that graduate programs have become vehicles through which law faculties "harvest additional bodies." ${ }^{20}$ The claim is that graduate students, at least at the master's level, generate "free money" for a law faculty because they fill seats in existing undergraduate classes and often pay high tuition (especially if they are international students). These tuition fees then subsidize the faculties' primary expenses, which are related to their undergraduate programs.

In Canada, some advocate for enhanced research-oriented programs at both the master's and doctoral levels. On this view, while graduate programs have improved since the publication of the Law and Learning report in $1983,{ }^{21}$ they remain impoverished because " $[t]$ he idea of the faculty as an intellectual community attracting a wide diversity of people with a wide diversity of research projects to be undertaken at all stages of a career has not really penetrated our consciousness.”22 This critique calls for a shift away from conceptions of the LL.M. as the principal graduate degree or as a "finishing school," and towards an understanding of graduate study in law as an opportunity for the advancement of knowledge and personal insight for the student. ${ }^{23}$ Moreover, as observed in both Canada and the US, despite law faculties' stated intentions to nourish future legal academics through doctoral studies, the existing programs eclipse the teaching dimensions of legal academia via a myopic focus on written scholarship. ${ }^{24}$

In sum, while rare, when graduate legal education is found in the discourse on the crises of the law faculty, it is positioned as either part of the problem, or partly a problem in and of itself.

\section{B. WHAT ARE THE SHORTCOMINGS OF THE CURRENT DISCOURSE?}

Given that, with limited exceptions, graduate legal education is absent from the conversation about the future of law faculties, the next question is, bluntly, so what? Of what significance is this absence? After all, it has not stunted the growth of the discourse.

Tamanaha, Failing, supra note 4 at 64 .

Consultative Group on Research and Education in Law, Law and Learning: Report to the Social Sciences and Humanities Research Council of Canada (Ottawa: Social Sciences and Humanities Research Council of Canada, 1983) [Law and Learning]. Law and Learning - the standard-bearer in the Canadian discourse on legal education - advocated for the development of strong graduate programs at Canadian law faculties as part of a larger project of solidifying law faculties' positions within the university and cultivating academic study of and in law. Twenty years later, Macdonald observed that many post Law and Learning changes to legal education reflected the aims of the report, including the increased number of law professors with doctoral degrees, higher quality graduate programs, broadened curricular offerings at the undergraduate level, increased interest in courses on empirical methods, and increased interdisciplinarity in research and hiring. Yet, he cautioned that "before we become too self-congratulatory, let us not ignore the evidence that, in many key respects, much has remained unchanged over the past two decades" (Roderick A Macdonald, "Still 'Law' and Still 'Learning'” (2003) 18:1 CJLS 5 at 5-6).

Macdonald, ibid at 19.

Ibid at 18; Law and Learning, supra note 21 at 83, 126, 157.

Anand, supra note 14 at 59, 93-94, 102, 115, 125, 129-30, 155; Hupper, supra note 14. On the myopic focus of doctoral programs, see Ann E Austin \& Melissa McDaniels, "Using Doctoral Education to Prepare Faculty to Work Within Boyer’s Four Domains of Scholarship” (2006) 129 New Directions for Institutional Research 51 at 55. 
We contend that forgetting graduate studies from the discourse compromises the discussion about the future of legal education and, as a result, impacts the future of law faculties. An initial concern is that leaving graduate studies out of the conversation is out of sync with an up-to-date snapshot of graduate programs in Canada. Since the Law and Learning report, there has been a general trend of growth in the number of faculties offering programs, the number of programs offered by those faculties, and the number of people in those programs. In 1983, 13 Canadian law faculties offered graduate programs. ${ }^{25}$ According to the Law and Learning report none of the programs were large, few had developed specialties, and all were underfunded. ${ }^{26}$ Thirty years later, 18 law faculties in Canada offer more than 60 graduate program configurations. ${ }^{27}$ Of those 18 , all offer master's degrees and all but four offer doctoral programs. ${ }^{28}$

The number of graduate students enrolled in Canadian law faculties has also grown significantly. Today, the number of newly enrolled master's students each year ranges from 625 to 664 and the number of newly enrolled doctoral students ranges from 98 to 114, for an annual total of 723 to 778 newly admitted graduate students. ${ }^{29}$ This represents a dramatic increase in the number of graduate law students studying in Canada since the time of the Law and Learning report, when there were only 260 full-time graduate students enrolled, in total, in Canadian law faculties. ${ }^{30}$

On the one hand, it is unsurprising that graduate legal education has not played a prominent role in the conversation about the future of law faculties. As many critiques call for practice-oriented legal education, the relevance of graduate programs gradually diminishes except to the extent that they offer professional specializations (in, for example, air and space law or tax law) ${ }^{31}$ On the other hand, it is surprising that so much of the

Law and Learning, supra note 21 at 18, 36.

\section{Ibid at 18.}

According to the faculties' websites, graduate programs are offered at all Canadian law faculties except the University of New Brunswick, University of Windsor, Lakehead University, and Thompson Rivers University. The number of program configurations includes the various Master's (e.g. thesis, non-thesis, essay, certificate, and specialization options) and doctoral programs on offer at Canadian law faculties, as described on the faculties' websites.

Those four being the University of Manitoba, University of Saskatchewan, University of Calgary (except in special cases), and the Université de Moncton.

The authors compiled these numbers based on a survey sent to graduate program directors at all Canadian law faculties that currently offer graduate programs. Every faculty responded. The survey questions were:

1. What is the current size, in terms of the average number of students, or range in the number of students, in your entering class of masters and doctoral students each year? Please indicate the numbers of entering doctoral students separately from the number of entering masters students and where you have very disparate masters programs, you may of course give separate numbers for each.

2. Would it be correct to say that in your Faculty, there is a significant contingent of international students amongst your graduate students?

3. For purposes of hiring new professors, is it a requirement of your Faculty that applicants hold a doctorate (or be in the process of completing doctoral studies) in Law or another discipline?

4. Are there any comments you could share on the changes that have occurred with respect to graduate studies in your Faculty over the past 10 years such as changes in size or scope of your graduate law programs?

Law and Learning, supra note 21 at 36.

Labeling an LLM program as "professional” does not necessarily exclude it from the world of ideas or from the main mission of the law faculty. Also, such programs can rely on innovative programming to meet particular needs of varied constituencies. Consider, for example, Osgoode Hall Law School's professional LLM programs which offer students, many of whom have been in the workforce for extended periods of time, the opportunity to pursue specialized graduate studies outside of the traditional law school environment, with exclusive graduate courses and online options. 
discourse on the future of law faculties does not contemplate graduate studies in a sustained way given that Canadian law faculties have been active in the arena of graduate studies over the past few decades. In designing and implementing graduate programs, faculties have invested considerable human and financial capital in recruiting, admitting, and funding graduate students, as well, of course, in teaching, supervising, mentoring, and evaluating them. ${ }^{32}$

A second concern is that the absence of graduate legal education from discussions about the future represents a missed opportunity. By failing to talk about graduate legal education, we miss out on an opportunity to contemplate and respond to the challenges and existential questions of graduate legal education. We avoid asking these questions: What is the place of graduate programs in Canadian law faculties? Which aspects of these programs are to be lauded and replicated? What are the present and future crises of graduate legal education? How should today's doctoral programs be designed in order to cultivate leaders of tomorrow? Similarly, the absence of graduate legal education from the discourse eclipses the opportunity to rely on graduate legal education as a lens through which to view undergraduate legal education. As a result, we miss out on the lessons to be learned by asking questions such as: what does the experience of graduate students in law reveal about the state of undergraduate legal education? And, what does the design of graduate programs entail for future undergraduate students in law?

A third concern is that excluding graduate legal education from the discourse contributes to the perpetuation of a problematic distinction. When the future of legal education is discussed in undergraduate terms alone, the existential "tug of war"33 between legal practice and legal theory is replicated. Graduate studies map onto legal academia and theory, while undergraduate studies map onto legal practice and the profession. This is problematic because it is much too simplistic to draw stark, mutually exclusive distinctions between the legal academy and the practicing bar or between theory and practice. ${ }^{34}$ Moreover, it generates the impressions that: (1) legal education programs can, or should, be categorized according to the career aspirations of their students; and (2) graduate and undergraduate education are, or should be, in separate silos within a law faculty, such that the future of one is not meaningfully connected to the future of the other.

In addition, over the past decade, there has been a general increase in the cumulative number of scholarships awarded by the Social Sciences and Humanities Research Council (SSHRC) to doctoral students in law. However, the number of new awards given each year has remained fairly constant since 2004, ranging from a high of 30 (2004 and 2007) to a low of 21 (2013). “Competition Statistics," online: Social Sciences and Humanities Research Council < http://www.sshrc-crsh.gc.ca/results-resultats/statsstatistiques/index-eng.aspx> (by adding together CGS Doctoral Scholarships and SSHRC Doctoral Awards awarded to doctoral students in law).

33 William Twining, Blackstone's Tower: The English Law School (London: Stevens \& Sons, Sweet \& Maxwell, 1994) at 2, cited in Paul Maharg, Transforming Legal Education: Learning and Teaching the Law in the Early Twenty-First Century (Aldershot, UK: Ashgate, 2007) at 271-72, and referred to in Van Praagh, supra note 11 at $\mathrm{n} 9$.

34 For a discussion of some of the competing ideas about legal education in Canada see Law and Learning Report, supra note 21 at 12-14. With respect to the relationship between theory and practice generally, Macdonald aptly summarizes: "Abstract, theoretical knowledge is a canvas on which students of law learn to paint particular proposals for addressing novel situations beyond the contemplation of general rules” (Roderick A Macdonald, "Does Law Have a Place in the Modern University? Or Every Great University Needs a Legal Studies Programme” LSE Law, Society and Economy Working Papers 4/2012, online: London School of Economics <www.lse.ac.uk/collections/law/wps/wps.htm> [Macdonald, "University”]). Note, however, the continued invocation of the traditional distinction: see e.g. LSUC Report, supra note 4; Kronman, supra note 5 at 264-70. 
In our view, this model is misguided. With respect to career aspirations, while many undergraduate law students intend to practice law and many graduate law students intend to be law professors, a university education in law cannot be defined solely by the career aspirations of its students. Many law graduates - whether from graduate or undergraduate programs - proceed to careers that are not captured by the traditional categories of practicing lawyer and professor. ${ }^{35}$ They are "dispersed into all sectors of society"36 and take up positions as executives, politicians, policy-makers, social justice advocates, legislative drafters, librarians, journalists, authors, consultants, mediators, law enforcement officers, and so on. Moreover, if we accept that a university education in law is an exercise in learning about just human interaction, in the course of which students learn about themselves, then we must also accept that a legal education can easily transform a student's interests and aspirations. As a result, we should not expect law students, whatever their level of study, to lock themselves into any particular category at the outset of their legal education.

With respect to silos, it is not the case that undergraduate and graduate programs are mutually exclusive or operate in separate watertight compartments. ${ }^{37}$ Within a law faculty, these programs overlap and intersect across time, physical space, social activities, aspirations, as well as the sites and personnel of teaching and learning. Some undergraduate law students will be future graduate students in law and, as such, also future law professors. A student's motivation to pursue graduate studies can be ignited (or stifled) — and the seed of his or her research project can be sown (or discarded) - during the student's undergraduate law program. Moreover, some graduate students are engaged in research on legal education, ${ }^{38}$ thereby becoming producers of knowledge on the subject. ${ }^{39}$ In addition, as is discussed in greater detail below in Part III.B, undergraduate and graduate students interact in the classroom; in other physical spaces in the faculty, from the library to the computer lab

Of course, even the traditional categories can be taken up in a range of forms: litigator, in-house counsel, law dean, judge, corporate lawyer, research lawyer, public interest advocate, and combinations thereof. Macdonald, "University," supra note 34. See also Blom, supra note 7 at 19; Macdonald, "Everyday Lessons," supra note 1 (in legal education, "[the] goal is not to stigmatise certain career choices, but rather to value all careers and thereby confront every student $\ldots$ with the challenges and responsibilities attendant upon the ethical deployment of legal knowledge in any type of practice” at 4-5).

37 Undoubtedly, graduate programs in law differ in meaningful ways from undergraduate programs. At an obvious level, admission criteria, program design, requisite time investment, and degrees awarded differ between the two types of study. Distinctions like these - as well as distinctions in the substance and depth of study and between different levels of graduate programs - should remain.

38 See e.g. David Sandomierski, Critical and Remedial Perspectives on Legal Education, In and Outside the Law School/Faculty of Law (SJD Thesis, University of Toronto) [unpublished]; Rochette, supra note 8; Mélanie Pascale Brunet, Becoming Lawyers: Gender, Legal Education and Professional Identity Formation in Canada, 1920-1980 (PhD Thesis, University of Toronto, 2005) [unpublished]; John O Mudd, Academic change and perspective in legal education (JSD Thesis, Columbia University, 1994) [unpublished]; Karen Hogarty, Legal Education in Scotland and Quebec (LLM Thesis, McGill University Institute of Comparative Law, 1991) [unpublished]; Douglas Dale McFarland, Self-Images of Law Professors: Rethinking Legal Education (PhD Thesis, University of Minnesota, 1983) [unpublished].

39 With respect to graduate students transforming from consumers of knowledge to creators of knowledge see Desmond Manderson, “Asking Better Questions: Approaching the Process of Thesis Supervision” (1996) 46:3 J Legal Educ 407. 
to the cafeteria; and at faculty events, both social and academic, such as "coffee house,"40 alumni receptions, guest lectures, job talks, and career information sessions.

While below we underscore the need to examine these interactions and optimize their pedagogical potential, here the point is that graduate and undergraduate programs in law do not unfold in silos and that the interactions between them have implications for the future. As a result, a discourse about the future of law faculties that fails to consider the role of graduate studies is incomplete, hinders inquiry into the interactions taking place within a faculty, and undermines the utility of graduate studies as an analytical lens through which to examine the faculty and its constituent parts.

\section{How CAN We Overcome These Shortcomings?}

One way to overcome the shortcomings revealed in the preceding section is by reframing the discourse. Instead of falling into the notorious "trap of academy versus profession," 41 and polarizing graduate and undergraduate studies, we should conceive of legal education in a holistic sense and view the law faculty as an institution with a single, broad mission: that of cultivating jurists. These jurists will, of course, have undertaken legal education at different levels and at different stages of their lives and will ultimately appear in many iterations in society, but the legal education they receive should prepare all of them "to understand the institutions, processes, and instruments through which human beings are able to discover and shape their beliefs, interests, and aspirations, to communicate these to others, and turn them into accomplishments." 42

It is reasonable to question the impact of what appears to be a mere terminological change. The intended effect, however, goes well beyond nomenclature. ${ }^{43}$ Conceiving of all legal education as having a common purpose, namely the cultivation of jurists, reconceptualises the law faculty as an integrated whole of "place, program, and people" - as a community of learners. ${ }^{44}$ Such an understanding of a law faculty necessarily includes the people, programs, and places of both graduate and undergraduate studies as well as their interactions.

The term jurist, which we suggest be used to reframe the discourse, has been associated with a number of differing contexts and connotations. At times, it is reserved for the most

40 "Coffee house” refers to a weekly afternoon tradition at McGill’s Faculty of Law. According to the Faculty website, it is "a chance to relax, have a beer or a soda, talk to friends, and make plans for the weekend. Some Coffee Houses are sponsored by law firms, and others are fundraising venues.... Either way, it's ... a place where students can chat with professors and get to know one another outside the classroom" ("Student life at the Faculty of Law,” online: McGill University <http://www.mcgill.ca/lawadmissions/student-life>). We put "coffee house” in quotes because it is also intended to signal similar collegial gatherings and traditions at other law faculties: e.g. "Domus” at Dalhousie University's Schulich School of Law (online: Domus Legis Society <http://www.domuslegis.ca>. For the important impact on identity and educational aspirations of students in the social setting of "coffee house," see Manderson \& Turner, supra note 1.

Van Praagh, supra note 11.

Roderick A Macdonald \& Jason MacLean, “No Toilets in Park” (2005) 50:4 McGill LJ 721 at 759.

While the terms "lawyer" and "jurist" are sometimes used interchangeably in everyday language, JJ Santa Pinter points out that while all jurists are lawyers, not all lawyers are jurists (JJ Santa Pinter, “About Jurists and Jurisprudence” (1968) 21 RHDI 92 at 95).

44 Van Praagh, supra note 11. On law faculties as "knowledge communities,” see HW Arthurs, “The Future of Law School” (2014) 51:4 Alta L Rev 705 at 710. 
revered of judges. ${ }^{45}$ In other contexts, it evokes the memory of the famous jurisconsults of Roman law - the legal consultants who embodied the Roman spirit of legal learning and whose knowledge and wisdom are credited with the development of law itself. ${ }^{46}$ The jurist to which we refer does not occupy any particular role, such as judge or jurisconsult, but calls to mind similar qualities including a vision of "law as learning ... according to rigorous requirements of reasoning," with a view to understanding "conditions of governance of complex personal relationships." ${ }^{47}$ Finally, the term is sometimes preceded by an adjective, such as "total" or "broadly-based." ${ }^{48}$ Professor Pue, for example, speaks of the need to educate "total jurists," those who learn more than the mechanics of law and in whom a sense of ethics and moral judgment is developed. For Pue, legal education must include "a commitment to shaping their innermost beings so as to produce the sort of professional most likely to make positive contributions to the larger community."49 Our conception of a jurist also embodies these aspirations.

While the term jurist is used in different contexts, one can identify several unifying currents. First, it is a general term and avoids pigeonholing law graduates into categories such as academic, theoretician, practitioner or policy-maker. ${ }^{50}$ Second, it evokes a calling that transcends the practising bar and the academy, one that incorporates contribution to society and legal thought, intellectual reflection as well as creative and critical thinking. ${ }^{51}$ The conception of the jurist developed by Roscoe Pound has been described as "a creative and moulding force in legal progress." 52

The importance of cultivating jurists is shared across graduate and undergraduate legal education. For both, there is a need to inculcate capacities for problem-solving, professionalism, ${ }^{53}$ judgment, intellectual curiosity, and self-awareness. As Roderick Macdonald has written, the essence of law studies is to teach how to deal with "the 31:7 Colum L Rev 1073.

Joseph Dainow, "The Civil Law and the Common Law: Some Points of Comparison” (1967)15:3 Am J Comp L 419 at 421 . The spirit of Roman law is characterized by an importance placed on values and approaches to law as well as on law's impact on society (see Alan Watson, The Spirit of Roman Law (Athens, Ga: University of Georgia Press, 1995) at 33-41).

H Patrick Glenn, Legal Traditions of the World, 4th ed (Oxford: Oxford University Press, 2010) at 137, 139.

Pue, supra note 11. Concerning "broadly-based jurists,” see Julie Bédard, "Transsystemic Teaching of Law at McGill: 'Radical Changes, Old and New Hats'” (2001) 27:1 Queen’s LJ 237 at 252, where in footnote 51, the author cites the Ad Hoc Curriculum Review Committee's Final Report to the Faculty of Law, McGill University (April 11, 1996) as the source of the term.

49 Pue, supra note 11 at 220.

50 According to Dorsett \& McVeigh, "the office of jurist is general and can be occupied in a number of different ways ... jurist as university person; jurist as educator; jurist as State functionary; jurist as legal advisor" (Shaunnagh Dorsett \& Shaun McVeigh, "The Persona of the Jurist in Salmond's Jurisprudence: On the Exposition of 'What Law Is ...”' (2007) 38:4 VUWLR 771 at 775).

51 Santa Pinter, supra note 43 at 95-97; Van Praagh, supra note 11. Regarding the pedagogical aspiration of creating critical-thinking jurists, see Rosalie Jukier, "The Impact of 'Stateless Law' on Legal Pedagogy" in Dedek \& Van Praagh, supra note 11 [Jukier, "Impact”].

$52 \quad$ Harold Dexter Hazeltine, "The Jurist’s Explanation of Legal Development in England and Elsewhere (General Preface)" in Roscoe Pound, Interpretations of Legal History (Cambridge: Cambridge University Press, 1923) vii at xiii.

53 For a revitalized notion of professionalism, see David Sandomierski, "Training Lawyers, Cultivating Citizens, and Re-Enchanting the Legal Professional” (2014) 51:4 Alta L Rev 739. 
complexities of people in interaction with each other." ${ }^{54}$ In our view, this is equally true for undergraduate and graduate law students, whatever roles they play in society.

With this vision of legal education and the holistic conception of a law faculty in mind, we move to examine more particularly how thinking about graduate legal studies contributes to the discourse on the future of legal education.

\section{THE FUTURE DISCOURSE: LESSONS FOR THE LAW FACULTY}

In Part II, we established that graduate legal education is largely absent from the current discourse and that such absence has negative consequences for the discourse and the law faculty. We contended that graduate studies can be brought into the discourse by recognizing the common purpose of graduate and undergraduate legal education as the cultivation of jurists and understanding the law faculty as an integrated whole. In this Part, we explore in greater depth some of the lessons that can be learned when we adopt these starting points. We demonstrate that thinking about graduate legal education is important to an analysis of the future of the law faculty and that it can help faculties grappling with their mission, the delivery of their programs and their future.

\section{A. The IMPACT OF GRAdUATE STUDIES ON A LAW FACULTY'S MISSION AND PLACE IN THE UNIVERSITY}

A "well-conceived legal studies programme can play a crucial role ... [in] inoculating the University against the virus of complacency" because it forces a confrontation with the question of what a university is. ${ }^{55}$ A graduate studies program can play a similar role for a law faculty by compelling it to confront its own mission. ${ }^{56}$ During the initial stages of program design, and the ongoing processes of implementation (review and reform) a law faculty should ask two questions: How does its mission fit within, or translate to, its graduate programs? Furthermore, to what extent do its graduate programs inform the faculty's overall mission ${ }^{57}$

While many law faculties have thought seriously about the design and delivery of their graduate programs, and have integrated goals regarding graduate recruitment and funding into their strategic plans, ${ }^{58}$ undergraduate and graduate legal education are thought to be separate endeavours. Many graduate programs operate alongside, and in the shadow of, their

$54 \quad$ Macdonald, “University,” supra note 34.

55 Ibid.

"Mission" refers to a law faculty's aims and ambitions and the positions it stands and strives for. It includes a faculty's conception of law and vision of legal education, along with the pedagogical, curricular, conceptual, linguistic, and legal reforms explicit and implicit therein.

57 These two questions logically presuppose that a law faculty has a well-defined sense of its own identity. This is not always the case. With respect to the American experience of doctoral studies generally, see Chris M Golde, "Preparing Stewards of the Discipline” in Chris M Golde \& George E Walker, eds, Envisioning the Future of Doctoral Education: Preparing Stewards of the Discipline (San Francisco: Jossey-Bass, 2006) 3 at 8.

$58 \quad$ See e.g. Osgoode Hall Law School, Experience Osgoode: Strategic Plan 2011-2016, online: York University <http://digital.yorku.ca/i/59910>; The University of British Columbia Faculty of Law, The UBC Law Strategic Plan, online: UBC Faculty of Law < http://wwwarc.law.ubc.ca/files/pdf/strat_plan/ UBC_Law_Strategic_Plan.pdf>. 
faculty's undergraduate program. ${ }^{59}$ This is not surprising given the relative youth of many graduate law programs, ${ }^{60}$ developed long after their undergraduate counterparts and their faculty's central mission. Thus, while a faculty's overall vision of legal education may in some way translate to its graduate programs, it was likely not conceived of to do so. Nor, as a result, do graduate programs, established separately from undergraduate studies, necessarily shape the overall mission of the faculty.

To illustrate, we use McGill's Faculty of Law as an example of how graduate legal education was largely forgotten in a major curricular overhaul that has come to define a faculty's vision of legal education and its distinctive mission. McGill's primary mission is its transsystemic orientation, which entails an integrated approach to legal pedagogy and legal thought characterized by the crossing of jurisdictional, disciplinary, linguistic, and cultural boundaries. ${ }^{61}$ From the outset of their legal education, undergraduate students are taught from multiple non-tradition-specific legal and interdisciplinary perspectives, and encouraged to be at home in different legal traditions and at ease with different legal languages. This mission was, however, conceived within the exclusive sphere of the undergraduate law program, without thought as to its impact on the Faculty's graduate programs. $^{62}$

In reality, many master's and doctoral students at McGill enroll in graduate programs within the Faculty's Institute of Comparative Law and take courses with comparative legal perspectives. ${ }^{63}$ However, like in most North American graduate programs in law, McGill's graduate students, particularly at the master's level, satisfy the bulk of their course requirements by taking upper-year undergraduate courses. ${ }^{64}$ This reflects the fact that the students already have undergraduate law degrees and should not repeat foundational courses. As such, McGill's LL.M. students cannot access first-year undergraduate courses, nor many compulsory second-year courses - the very courses that aim to cultivate the transsystemic

Osgoode Hall Law School’s strategic plan states, “Osgoode has a strong JD student community and a strong Graduate student community but too few opportunities for JD and Graduate students to engage with one another" (ibid at 5).

60 For example, the University of Alberta's doctoral program in law was launched in 2009 and the doctoral program at Université du Québec à Montréal was launched in 2007, with the first theses submitted in 2013.

61 McGill’s Transsystemic Program was implemented in 1999. See Yves-Marie Morissette, “McGill’s Integrated Civil and Common Law Program” (2002) 52: 1 \& 2 J Legal Educ 12; Nicholas Kasirer, "Bijuralism in Law's Empire and in Law's Cosmos” (2002) 52: 1 \& 2 J Legal Educ 29; David Howes, "Maladroit or Not? Learning to Be of Two Minds in the New Bijural Law Curricula" (2002) 52: 1 \& 2 J Legal Educ 55; Armand de Mestral, "Guest Editorial: Bisystemic Law-Teaching: The McGill Programme and the Concept of Law in the EU" (2003) 40:4 CML Rev 799; Harry Arthurs, "Madly Off in One Direction: McGill's New Integrated, Polyjural, Transsystemic Law Programme" (2005) 50:4 McGill LJ 707; Rosalie Jukier, "Where Law and Pedagogy Meet in the Transsystemic Contracts Classroom” (2005) 50:4 McGill LJ 789; Peter L Strauss, "Transsystemia: Are We Approaching a New Langdellian Moment? Is McGill Leading the Way?” (2006) 56:2 J Legal Educ 161; Helge Dedek \& Armand de Mestral, "Born to be Wild: The 'Trans-systemic' Programme at McGill and the DeNationalization of Legal Education” (2009) 10:7 German LJ 889.

62 Admittedly, while graduate programs in law existed at the time of this major curricular overhaul, they were not as large or as prominent as they are today.

63 Note, however, that comparative law is not synonymous with the transsystemic approach. The latter is characterized by the "transformation of comparative legal pedagogy from the sequential to the integrated; by the creation of blended courses that incorporate a multiplicity of perspectives, voices and lenses in a 'dialog with otherness,' and through inclusion and integration of multiple legal traditions and alternative sites of law" (Jukier, "Impact," supra note 51 [footnotes omitted]).

64 Our informal survey of Canadian law faculties (supra note 29) indicates that while not all graduate programs operate in this manner, many require that LLM students take upper-year undergraduate law courses. 
thinker. The effect is that while the stated objective of McGill's graduate programs is to offer students the ability "to explore ideas and projects in an environment that is uniquely comparative and pluralist," 65 the design and implementation of the graduate programs themselves have not institutionalized the faculty's dedication to transsystemia.

Therefore, graduate students, particularly at the LL.M. level, must take upper-year undergraduate courses without any formation in the primary pedagogical focus of the faculty and are expected to "catch on." When these courses are organized in accordance with the transsystemic approach, the master's students are bound to be either confused or unable to engage fully with the course material and pedagogy. ${ }^{66}$ Moreover, professors in classes with both upper-year undergraduates and graduate students may struggle with how best to pitch the course given the uneven preparation between these two groups of students. ${ }^{67}$ This all perpetuates the perception that graduate studies are secondary to the faculty's main mission of educating undergraduate law students and shows that the extensive resources exerted to fulfill the undergraduate mission are not used effectively in the graduate context.

In practice, despite not being formalized in graduate program design, McGill's transsystemic model can have positive effects on graduate students. They might be exposed to transsystemic thinking in their interactions with their supervisors and in the classroom where they interact with undergraduate students who have developed a transsystemic mindset. Moreover, opportunities for cross-fertilization are enhanced by the impact of graduate students on undergraduates (see Part III.B below). The combined presence of graduate and undergraduate students in the classroom can help reinforce the multiplicity of perspectives that characterizes the McGill pedagogical approach. Without question, McGill's graduate student body, particularly given its international makeup, ${ }^{68}$ aligns with the mission of McGill's undergraduate law program. However, the extent to which the graduate students benefit from the faculty's overall transsystemic mission is due more to serendipity than to deliberate institutional design. ${ }^{69}$ What, then, can be gained by thinking explicitly about the graduate program in relation to McGill's overall mission?

Obviously, including graduate studies in the discourse would provide an opportunity to assess how McGill's understanding of law is, and should be, incorporated into the graduate curriculum. In light of the extensive investment that McGill's law faculty has made to its undergraduate curriculum, it makes sense to consider how that investment could benefit the graduate students other than on an ad hoc basis. Moreover, such deliberate reflection would demonstrate that while the Faculty has been successful in creating and delivering effective transsystemic courses at the first-year and compulsory second-year undergraduate levels, precisely the courses graduate students are excluded from taking, it has been less successful

See McGill's Graduate Studies in Law website, “About Graduate Studies in Law,” online: McGill University <http://www.mcgill.ca/law-gradprograms/about/> [emphasis added].

66 An additional challenge at McGill is that while undergraduate students must be passively bilingual in French and English in order to access course materials in both languages, graduate students need not be bilingual for purposes of admission.

67 This uneven preparation refers to the fact that graduate students already hold law degrees and yet are uninitiated in the faculty's particular pedagogical culture.

Generally, international students make up two-thirds of McGill's LLM class.

This is reinforced by the fact that graduate students are not required to incorporate comparative or transsystemic perspectives into their graduate study and both LLM and doctoral students may pursue research in areas that do not fall within McGill's stated mission. 
at carrying out its transsystemic aspirations at the upper-year course level. This reveals a lacuna in the execution of the Faculty's mission and provides an opportunity to reflect on whether the upper-year curriculum can be moved more into the culture of the Faculty.

Another lesson that law faculties can learn by introducing graduate studies into the discourse pertains to the law faculty's place within the larger university context. Much has been written about the existential crises of the law faculty within the university: "Law schools have always been shaped by the relationship between their dual roles as a gateway to the legal profession and as an academic institution." ${ }^{\text {70 }}$ Unease with associating the law faculty with its academic counterparts has come from within the legal profession and those charged with evaluating the state of legal education. However, some of this ambivalence also comes from the rest of the university. Academics from other faculties are often skeptical about the research vocation of the law faculty, doubting whether reading treatises and judicial cases constitutes scholarly research.

Yet, taking up the "intellectual currents in the rest of the academy" "fundamental research on law," "2 there is no doubt that "research in the law schools has come to identify itself rather more with its counterparts in other university departments and less predominantly with research... by the legal profession."73 In our view, a serious program of graduate studies reinforces law as a university discipline and secures the law faculty's vitality as an academic institution. Solidifying the research vocation of the law faculty through its program of graduate studies occurs not only because a primary part of graduate studies, particularly at the doctoral and research master's level, is the pursuit of research. It is also because graduate students can enhance the scholarly work of professors with whom they interact, whether in a supervisory relationship, as research assistants, or as co-authors of scholarly articles. ${ }^{74}$

The place of the law faculty within the university is further reinforced by graduate students who pursue interdisciplinary research. For example, doctoral students at McGill have recently written dissertations on legal history, law and environmental studies, law and development, law and education, and law and communications. These students may have cosupervisors or advisory committee members from faculties outside of law and may participate in multidisciplinary research teams and institutes within the university. ${ }^{75}$ In this way, they help link the law faculty and other branches of the university. For these reasons,

$70 \quad$ Blom, supra note 7 at 20. The place of the law faculty within the university has had different histories in the continental civilian tradition and common law tradition. In the former, the academy has always been central to legal education. See Glenn, supra note 47 at 140-42; Thomas E Carbonneau, "The French Legal Studies Curriculum: Its History and Relevance as a Model for Reform” (1980) 25:4 McGill LJ 445 at 446; John Henry Merryman \& Rogelio Pérez-Perdomo, The Civil Law Tradition: An Introduction to the Legal Systems of Europe and Latin America, 3d ed (Stanford: Stanford University Press, 2007) at 56. The same is not true of the common law tradition. See Glenn, ibid at 241; Law and Learning, supra note 21 at $12-14$.

71 Denise G Réaume in "Rethinking the Laissez-Faire Law Curriculum: Fostering Pluralism and Interdisciplinarity” (Conference Paper, Spring 2001), [unpublished], cited in Pue, supra note 11 at 216 , n 39.

Law and Learning, supra note 21 at 65-70.

Blom, supra note 7 at 11.

See Anand, supra note 14 at 161; Hupper, supra note 14 at 426. See also Part III.B.3 below.

For example, McGill's Institute for the Public Life of Arts and Ideas is a collaboration between the faculties of law, arts, education, music, management, religious studies, and architecture. Several McGill doctoral students participate by way of reading groups and research projects. 
a serious program of graduate studies can help to cultivate and sustain the conception of a law faculty as a pluralistic intellectual community and dynamic research institution and to establish its place firmly within the wider context of the university. ${ }^{76}$

\section{B. THE IMPACT OF THINKING OF A LAW FACULTY AS AN INTEGRATED WHOLE}

Excluding graduate studies from the discourse, and treating undergraduate and graduate law programs as if they operate in separate silos, result in a lost opportunity to examine the role and impact of graduate studies on a faculty's undergraduate program and its students, and vice versa. It is a missed chance to ask: is the education of either graduate or undergraduate students enriched because they study in a faculty that is an integrated whole of people, place, and programs rather than in an institution reserved only for undergraduate or graduate study?

As noted earlier, ${ }^{77}$ undergraduate and graduate law students interact in many ways within the law faculty - in classrooms, in other physical spaces, in faculty activities, and in their access to professors and personnel. It is helpful to examine these interactions in order to understand better the implications of locating graduate and undergraduate students within a single law faculty. Ultimately, learning is social; when students have opportunities to interact within a vibrant intellectual community rooted in a common sense of purpose, they are more likely to collaborate, share ideas, accumulate feedback, and learn. ${ }^{78}$

\section{THE PRESENCE OF GRADUATE AND \\ UNDERGRADUATE STUDENTS IN CLASSROOMS}

The fact that many master's students take upper-year undergraduate law courses ${ }^{79}$ has important ramifications for both professors and students.

For the professor, the presence of graduate students in a traditionally undergraduate course can pose pedagogical challenges resulting from two factors. First, the graduate students in the course already hold an undergraduate law degree. As discussed earlier, at a minimum, this can make it difficult to find the right level at which to pitch the course. Second, many of these graduate students are international students from a variety of legal jurisdictions and cultural backgrounds. ${ }^{80}$ The challenge is to accommodate these two factors in the design of the course, its delivery, materials, and evaluation. The level of knowledge, experience, and backgrounds of the graduate students simply cannot be ignored. While this adds a challenge,

As Thomas Carbonneau, supra note 70 at 476 has explained, "law schools are university institutions which, although they have a strong commitment to professional endeavor, also have the responsibility of furthering the pursuit of knowledge and preserving intellectual traditions and of acting as the impartial and independent repositories of ideas."

77 See Part II.B, above.

78 Chris M Golde et al, “Advocating Apprenticeship and Intellectual Community” in Ronald G Ehrenberg \& Charolotte V Kuh, Doctoral Education and The Faculty of the Future (Ithaca: Cornell University Press, 2009) 53 at 59, 62.

$79 \quad$ See Anand, supra note 14 at 69 . See also supra note 64.

80 Our survey of Canadian law faculties reveals that the proportion of international students in graduate programs varies from faculty to faculty and from year to year (supra note 29). Most Canadian law faculties reported some measure of international student representation in their graduate programs. 
it is also an opportunity for the professor to transform the mixed composition of the course into a pedagogical benefit. It can serve as an occasion to pose different questions, change the conversation in the classroom, and enrich class discussion by inviting the graduate students to share their perspectives, as shaped by the social and political contexts of their previous legal education and experiences. ${ }^{81}$ For a law faculty like McGill's, which strives to expose law students to various hypotheses and lenses through which to think about law and legal principles, having graduate students from different countries and legal systems integrated into the classroom serves its mission.

For undergraduate students, the presence of graduate students in the classroom can also have a positive effect. Exposing undergraduate law students to graduate students from multiple backgrounds, legal traditions, educational formations, and career aspirations can broaden the lenses through which they view the course materials. It can expose them to different perspectives about the subject and its social and legal context, inspire them to ask different questions about law itself, open their eyes to different legal methodologies and different ways of knowing law, and underscore the multiplicity of opportunities (including graduate study) that exist for law graduates, aside from traditional legal practice.

What, however, is the impact of the shared classroom on graduate students? On the one hand, it is reasonable to question a model of graduate legal education that is not tailored specifically for graduate students, a model that has been disparaged as being merely a fourth year of undergraduate law studies. ${ }^{82}$ It has also been criticized because it leaves international graduate students to "sink or swim" in upper-year undergraduate courses that they must take without adequate preparation or orientation. ${ }^{83}$

On the other hand, it is currently unrealistic for Canadian law faculties to mount completely distinct law programs and course offerings at the undergraduate and graduate levels. While the pedagogical consequences of this model require further exploration, there are positive aspects to the shared classroom. ${ }^{84}$ Allowing master's students to take undergraduate law courses expands their available course selection and may introduce them to professors with whom they would not otherwise come into contact. Further, for graduate students pursuing degrees at law faculties that differ in substantive ways from their undergraduate faculties, the students can access unfamiliar subject matters or familiar subject matters presented differently. ${ }^{85}$ Moreover, graduate students interested in professorial careers can benefit from sharing classrooms with undergraduate students because in doing so, they witness professors in formal interaction with students at a time when their minds are turning towards their future as pedagogues.

Leon E Trakman, “The Need for Legal Training in International, Comparative and Foreign Law: Foreign Lawyers at American Law Schools” (1976) 27:4 J Legal Educ 509 at 549.

Recall Macdonald's “finishing school” comment (Macdonald, supra note 21 at 18). See also Tamanaha, Failing, supra note 4 at 64.

Julia E Hanigsberg, “Swimming Lessons: An Orientation Course for Foreign Graduate Students” (1994) 44:4 J Legal Educ 588 at 590; Trakman, supra note 81 at 549-50.

Hanigsberg, ibid at 590; Trakman, ibid.

As Hanigsberg notes, North American legal education is based on problem-solving, inductive analysis, and the relationship between law and social sciences, which may be different to the model of legal education to which a graduate student was previously exposed (Hanigsberg, ibid at 593-94). 
Finally, in the classroom, undergraduates can become informal teachers of their graduate peers. The graduate students might learn, for example, from their undergraduate colleagues' comparative perspective on substantive legal issues or from their approaches to legal problem-solving, as cultivated by their law faculty's approach to legal education and methodology. In light of these dimensions of undergraduate and graduate interaction, while we need to interrogate the design of master's programs in law, as long as the current mixed model remains in place, we should strive to optimize the benefits derived from programmatic overlap.

Graduate students, of course, are not only found in the undergraduate classroom as fellow students. Some graduate students, largely at the doctoral level, take on formal teaching roles in law courses. They may be sessional lecturers, teaching fellows, ${ }^{86}$ guest lecturers, or seminar moderators, particularly when the course covers material within the graduate student's sphere of research. These opportunities provide graduate students with valuable teaching experience, particularly when they incorporate a formal dimension of learning to teach under the mentorship of a professor. ${ }^{87}$

Further, while doctoral students are frequently referred to as "tomorrow's teachers," ${ }^{88}$ their presence as pedagogues in the classroom results in them being today's teachers. Not only does this link graduate studies and legal pedagogy more explicitly for undergraduate law students, it may also enable undergraduates to benefit from pedagogical practices, be they technological or experiential, that differ from those of more established professors. Graduate students may have been exposed to newer pedagogical initiatives during their post-secondary education and have had more opportunities to engage in experiential, clinical, and interdisciplinary teaching methods in their own law studies, leading them to be more apt to use these pedagogies effectively in the classroom.

\section{The Presence of GRAduAte StUdents IN PHYSICAL SPACES AND ACTIVITIES}

In a law faculty, the mix of graduate and undergraduate students extends beyond the classroom, permeating other spaces, both social and studious. In these settings, casual conversation will sometimes overshadow substantive dialogue and, at times, it may seem like little legal learning is taking place. However, sharing social and study space not only integrates graduate students into the law faculty, but also has pedagogical potential. Substantively, both the undergraduate and graduate law students may develop a more multifaceted understanding of law, legal study, and legal practice. More fundamentally, informal discussions in the "ordinary and unexamined moments" occurring in socially-constructed

At McGill, the Teaching Fellowship program gives doctoral students in law an opportunity to gain indepth teaching experience. Under the supervision of a professor, teaching fellows engage in all aspects of a course, including designing a syllabus, selecting materials, developing learning exercises, integrating technology in the classroom, designing assessments, evaluating student work, providing feedback, and meeting with students (“Teaching Fellowship,” online: McGill Law Graduate Fellowships \& Awards Calendar <http://www.mcgill.ca/internalawards/faculty-dept-awards/law>).

$87 \quad$ This is addressed further below in Part III.C.

88 McGill explicitly uses the phrase “Teaching Tomorrow's Teachers” to describe its doctoral program and, in particular, its Teaching Fellowship Program (supra note 86). See also Anand, supra note 14 (who refers to doctoral programs as the legal academy training its successors at 159); Hupper, supra note 14 (who states that “the degree's distinctiveness lies in its preparation for an academic career” at 445). 
spaces become sites in which students can test their skills of legal reasoning and justification, and explore their understandings of legal methodology, with students inculcated in different educational modes and levels. ${ }^{89}$ These informal encounters can contribute to students' ongoing processes of personal development and identity-formation within their legal education. Further, students can use these interactions to learn about, and test the boundaries of, the culture of the faculty. This culture, aptly characterized as "the hidden curriculum," has an important effect on learning outcomes, ${ }^{90}$ as it sends "powerful messages about purpose, commitment, and roles." ${ }^{91}$

Graduate programs also bring graduate students into the activities of the law faculty, creating conditions for interaction between students at both levels of study. For example, professors might form research teams with both graduate and undergraduate research assistants. This "multi-generational” enterprise offers each team member the chance to learn from the others' experience and knowledge, and creates opportunities for formal and informal mentorship regarding research techniques, writing skills, legal methodology, and advocacy. Similar opportunities exist when graduate students coach undergraduate moot teams, hold information sessions on topics such as applying for court clerkships or graduate programs, and join faculty activities traditionally reserved for undergraduate law students, such as law journal editorship.

Given the potential for learning in these informal interactions, law faculties ought to investigate the educational value of such encounters and consider whether institutionally encouraging these, or other, opportunities are in the students' interests. Obviously, an institutional effort cannot replicate teaching and learning moments that arise spontaneously. However, where determined to be appropriate, opportunities for interaction could be offered by the faculty through, for example, graduate student mentorship of undergraduate students' independent research, opportunities for graduate students to judge undergraduate moots, and graduate student membership on law journal editorial boards. ${ }^{92}$

\section{THE IMPLICATIONS OF GRADUATE STUDENT-PROFESSOR RELATIONSHIPS}

It is usually assumed that graduate students are the primary beneficiaries of the graduate student-professor relationship. ${ }^{93}$ Professors are graduate students' teachers, mentors, sources

Manderson and Turner explain that the socialization of legal education occurs outside the classroom and emphasize the powerful nature of "ordinary and unexamined moments" (Manderson \& Turner, supra note 1 at 653). On identity formation by locating the self in relation to others, see Macdonald \& Glover, supra note 1 at 672 .

$90 \quad$ Golde et al, supra note 78 at 59 citing Thomas Bender, "Expanding the Domain of History” in Chris M Golde \& George E Walker, eds, Envisioning the Future of Doctoral Education (San Francisco: JosseyBass, 2006) 295 at 305. A faculty's intellectual community refers to "how people wrestle with ideas, how teaching is valued, how students learn to engage with senior colleagues, how failure is treated, how people work together, and how independence and risk taking are viewed” (Golde et al, ibid).

$91 \quad$ Golde et al, ibid; Lynn McAlpine \& Anila Asghar, "Enhancing Academic Climate: Doctoral Students as Their Own Developers” (2010) 15:2 International Journal for Academic Development 167.

92 Of course, neither the proliferation of activities nor interaction alone is a sufficient condition of greater intellectual engagement. Individuals need to interact with creative, thoughtful, passionate, and interested people and activities must be evaluated in light of their intended outcomes (Golde et al, ibid at 59-64). This assumption glosses over the reality that the benefits of the supervisory relationship are contingent on the existence of a positive, reciprocal, and respectful relationship between graduate student and supervisor. On the supervisory relationship, see Manderson, supra note 39. 
of expertise, colleagues, friends, and, of course, supervisors, the traditional cornerstone of graduate studies. The importance of a strong supervisory relationship is crucial; graduate students learn not only research and writing techniques from their supervisors, but also valuable lessons in scholarly socialization and pedagogy, as they learn how to be supervisors themselves in the future. ${ }^{94}$ While faculties and universities may offer workshops on supervision, these are rarely compulsory. Given the important formative implications of the supervisory relationship, faculties should do more to ensure that positive supervisory relationships are cultivated by articulating clear expectations, deliberately educating their professors in the art of supervision, assisting their new faculty members in finding their supervisory voice, and implementing some measure of oversight. ${ }^{95}$

However, in envisioning graduate student-professor interactions, the focus is rarely on the potential positive impact on professorial work. The impact on professorial research is perhaps the most obvious. Professors can learn substantive material from their graduate students, which may inspire or relate to their own research agendas. ${ }^{96}$ But, less often recognized is the impact on teaching in undergraduate classes. Professors who supervise graduate students also typically teach undergraduate courses, and these professors may find themselves incorporating their graduate students' research, methodologies, or perspectives into their undergraduate classrooms, whether in course materials, lecture content, or exam questions. In these ways, professorial interactions with graduate students can ricochet into, and enrich, undergraduate learning in a law faculty.

\section{THE IMPACT OF TODAY'S DOCTORAL EDUCATION ON TOMORROW'S LAW FACULTY}

Quite simply, many of today's doctoral students will be tomorrow's leaders of legal education. ${ }^{97}$ They will be the future teachers, authors, deans, associate deans, mentors, supervisors, committee chairs, and colleagues. In these capacities, they will play a decisive role in the quality of formal legal education offered in the future. As a result, when the discourse on the future of the law faculty fails to consider graduate legal education, it is necessarily incomplete.

Today's law faculties are responsible for educating these doctoral students. Fulfilling this responsibility is challenging because future scholars will lead scholarly lives different from those of the present ${ }^{98}$ and such lives will unfold in the midst of known, as well as unknown,

See e.g. Cheryl Amundsen \& Lynn McAlpine, “'Learning Supervision’: Trial by Fire” (2009) 46:3 Innovations in Education and Teaching International 331 [Amundsen \& McAlpine, "Learning”]; Lynn McAlpine \& Cheryl Amundsen, "Challenging the Taken-for-Granted: how research analysis might inform pedagogical practices and institutional policies related to doctoral education” (2012) 37:6 Studies in Higher Education 683 [McAlpine \& Amundsen, "Challenging”].

95 McAlpine \& Amundsen, “Challenging,” ibid; Benita J Barnes \& Ann E Austin, “The Role of Doctoral Advisors: A Look at Advising from the Advisor’s Perspective” (2009) 33:5 Innovative Higher Education 297.

$96 \quad$ Anand, supra note 14 at 161; Hupper, supra note 14 at 426.

97 In this section, we focus on doctoral education in law rather than graduate legal studies generally. We do so because our survey (supra note 29) shows that the majority of law faculties in Canada have a de facto or de jure requirement that newly hired professors hold a doctorate. 98 Regarding doctoral studies in general, see Ann E Austin, "Creating a Bridge to the Future: Preparing [Austin, "Bridge”]; Ann E Austin, "Preparing the Next Generation of Faculty: Graduate School as Socialization to the Academic Career" (2002) 73:1 Journal of Higher Education 94 [Austin, "Next Generation”]. 
crises. Accordingly, what should law faculties do today in relation to doctoral education that will contribute to the success of legal education tomorrow?

The points below begin to formulate an answer. Taken individually, the points deal with the purpose, pedagogy, and context of doctoral education; taken collectively, they reflect an approach to doctoral education in law that is concerned not with what graduates of doctoral programs do, but with who they are and will continue to become. ${ }^{99}$ Such an approach flows naturally from a conception of legal education that aims to cultivate jurists with the integrity, capacity, and inclination to bear the weight of the discipline's future. ${ }^{100}$

At present, doctoral programs do not attend sufficiently to developing students' scholarly identities beyond those of a lone researcher or preparing them for the expectations, realities, and diversity of scholarly life. ${ }^{101}$ Given that doctoral education is the defining period for scholarly formation, ${ }^{102}$ law faculties should consider how to adapt their programs to assist the next generation of legal scholars. The starting point is to design doctoral programs that educate students in the multiple dimensions of scholarly life. In identifying these dimensions, the literature on doctoral education is helpful as it sets out frameworks for conceptualizing the "domains of scholarship" or "skills of stewardship" that should be at the heart of doctoral programs. ${ }^{103}$ In some ways, these frameworks reflect the understanding that the work of a university professor is divided between commitments to teaching, research, community, and governance. Ultimately, they overlap conceptually and coalesce into a general model that applies to doctoral education in law. On this model, doctoral students should have the opportunity to learn the skills, values, and principles associated with four interrelated dimensions of scholarly life: the scholarship of discovery; governance and community engagement; teaching; and integration and interdisciplinarity.

First, the scholarship of discovery, the domain directed at generating and building knowledge, aligns with the familiar conception of doctoral studies as an education in research and writing a dissertation. ${ }^{104}$ A doctoral program in law attuned to this domain would strive to engage students in a process of questioning, ${ }^{105}$ learning to articulate questions with legal dimensions and investigate those questions through well-suited disciplinary and interdisciplinary methodologies and theoretical frameworks. ${ }^{106}$ Doctoral students would also learn how to assess the quality and rigour of research results and communicate them

Macdonald, “Everyday Lessons,” supra note 1 at 10-12; McAlpine \& Amundsen, “Challenging,” supra note 94 at 693.

This is consistent with the concept of stewardship articulated in the Carnegie Foundation collection on doctoral education (Golde, supra note 57). Stewardship encompasses sets of roles, skills, and principles, the mastery of which is necessary for generating, conserving, and transforming knowledge, as well as preparing the next generation of stewards.

McAlpine \& Amundsen, “Challenging,” supra note 94 at 689-93; Keiko Rasanen \& Kirsi Korpiako, "Supporting Students in Their Professional Identity Projects" (2011) 33:1 Studies in Continuing Education 19; Lynn McAlpine \& Judith Norton, "Reframing our approach to doctoral programs: an integrative framework for action and research" (2006) 25:1 Higher Education Research \& Development 3; Austin, “Next Generation,” supra note 98; Austin, “Bridge,” supra note 98. Golde, supra note 57 at 5; Austin \& McDaniels, supra note 24.

Golde, ibid; Austin \& McDaniels, ibid; Ernest L Boyer, Scholarship Reconsidered: Priorities of the Professoriate (Princeton, NJ: Carnegie Foundation for the Advancement of Teaching, 1990) at 15-25; Golde et al, supra note 78. See supra note 100 for an explanation of concept of stewardship.

See Austin \& McDaniels, supra note 24 at 52-53; Golde, supra note 57.

Manderson, supra note 39. For the types of questions to be asked, see Macdonald, “University,” supra note 34 at 11-12.

Manderson, supra note 39; Golde, supra note 57 at 10. 
effectively, whether through publication, inclusion in course syllabi, presentation at conferences, or reflection on professional blogs. Further, these doctoral students would develop an understanding of the history and foundational ideas of law as a discipline. ${ }^{107}$ Legal scholars must be able to situate their knowledge in the field as a whole and know when to discard, maintain, or transform existing disciplinary knowledge. ${ }^{108}$

Second, the domain of community engagement involves using disciplinary knowledge, skills, and judgment to address "individual, institutional, and societal problems." 109 This domain is broad, encompassing the gamut of contributions that a legal scholar can make to the community, whether in service to the faculty, the university, or external constituencies. Legal scholars might sit on faculty curriculum committees, serve on university disciplinary committees, chair corporate or community boards, advise on court cases, write opinion pieces for newspapers, or teach continuing education seminars to practitioners. While law faculties need not afford their students formal opportunities in all community endeavours, they should provide a range of possibilities so that doctoral students can map the possibilities for their personal contribution and cultivate the skills necessary to execute their objectives. As one strategy, law faculties should integrate doctoral students more fully into their governance committees. Institutional service, usually overlooked in doctoral education, is an opportunity for aspiring scholars to learn the tacit knowledge and values of the academy and to gain a better understanding of how institutional factors bear on scholarly work. ${ }^{110}$ It is also an important opportunity for students to develop independent ways of thinking about their own scholarly identity, future contribution, and leadership. ${ }^{111}$

Third, teaching is a foundational part of a scholar's life, regardless of where it occurs and to whom it is offered. ${ }^{112}$ Law faculties that aspire to high-quality legal education in the future should help their doctoral students develop their identities as law teachers. An education in teaching law entails more than offering doctoral students opportunities for classroom teaching. It requires learning about legal education - its history and place in the university, the ways in which law can be taught, strategies for integrating and balancing teaching and other domains of scholarship, and the context in which it takes place. ${ }^{113}$ It also entails learning how to teach, ideally in a mentored context. ${ }^{114}$ While doctoral students have informal opportunities to learn about law teaching through observation and interaction with professors and students in the law faculty, a doctoral program that takes the cultivation of successful educators seriously should also provide students with formal "learning to teach" 
opportunities, such as legal education seminars and teaching mentorship and fellowship programs. $^{115}$

Finally, in the domain of "integration," scholars aim to "make new connections within and among disciplines."116 This is the realm of interdisciplinarity, where scholars connect ideas and problems across domains. Just as all doctoral students in law should develop an understanding of the span of law as a discipline and how its constituent parts fit together in the grand scheme, they should also all acquire a sense of other disciplines in order to "know the differences between disciplinary views of the world, and be able to appreciate and communicate across traditional boundaries," creating a context for comparison of their own disciplinary knowledge and experience within the discipline and faculty of law. ${ }^{117}$ An education in the skills and principles of integration can take many forms. For doctoral students undertaking interdisciplinary research, law faculties can establish formal mentorship and supervisory relationships between the student and professors in multiple disciplines or consider offering interdisciplinary degrees. ${ }^{118}$ Others might gain exposure to interdisciplinarity through participation in pan-university research teams, institutes, or reading groups.

A doctoral program that attends to the four domains of scholarship cannot rely on the supervisory relationship as its signature approach to teaching. ${ }^{119}$ A doctoral student cannot expect to explore all the possibilities of a scholarly identity through a one-on-one relationship with a single supervisor, and one professor cannot be expected to provide this to each of his or her doctoral students. Moreover, given the growth of the discipline and the interdisciplinary issues implicated by legal research, the work of graduate students frequently does not match that of just one professor. This suggests that the pedagogy of doctoral programs should be dispersed so that doctoral students engage with multiple mentors of different generations, strengths, and interests. ${ }^{120}$ When implemented effectively, with institutional mechanisms in place to address issues of resource allocation, accountability, and collaboration, ${ }^{121}$ these multiple "apprenticeship" relationships could actively promote learning, independence, and agency for students, and expand their formative education in the "skills, practices, and dispositions" of scholars. ${ }^{122}$

McGill's Law Faculty offers each of these programs (concerning teaching fellowships, see supra notes 86,88 ). None, however, is mandatory and the faculty should consider whether any should be. Law faculties could also encourage doctoral students to join associations related to law teaching (such as the Canadian Association of Law Teachers), invite doctoral students to be seminar leaders or guest lecturers, include doctoral presentations in faculty research weeks and speaker series, and, as was noted earlier, establish roles for graduate students as mentors to undergraduate students undertaking research.

Austin \& McDaniels, supra note 24 at 53.

Golde, supra note 57 at 12; McAlpine \& Asghar, supra note 91 at 169.

Consider for example, the Interdisciplinary PhD programs at Dalhousie University ("Interdisciplinary PhD," online: Dalhousie University <http://idphd.grad.dal.ca/>); the University of Victoria ("Interdisciplinary program (INTD)," online: University of Victoria <http://www.uvic.ca/graduate studies/programs/home/programdescriptions/programs/interdisciplinary.php>); the interdisciplinary course requirements for doctoral students in law at UBC ("Doctors of Philosophy in Law (PhD)," online: UBC Faculty of Law <http://wwwarc.law.ubc.ca/files/pdf/graduate/PhD_Description.pdf >).

McAlpine \& Asghar, supra note 91 at 176; Golde et al, supra note 78 at 56-57.

Golde et al, ibid at 55.

Ibid at 57-58; Austin, "Bridge," supra note 98 at 121-23.

Golde et al, ibid at 55 . 
The context within which doctoral education takes place is equally important. A faculty's institutional culture and intellectual community constitutes the "invisible curriculum" of a doctoral program and is the environment in which doctoral students are informally educated in disciplinary and institutional values, the informal dimensions of academic life, and the principles of excellence and virtue of scholarship. ${ }^{123}$ A law faculty cannot plan for all of the informal learning that takes place within it, but it can create conditions conducive to the intellectual community and culture it seeks to build. Research into doctoral studies indicates that a vibrant, healthy intellectual culture, one that values debate and collaboration, is a necessary condition for the core work of doctoral education and offers "a supportive context for the work of research, teaching, and, of course, learning."124 Such a culture is broadly inclusive, a safe space for error and reflection, interactional, and purposeful. ${ }^{125}$ It cultivates independence of thought but not isolation, creativity but not lack of rigour, and shared responsibility for doctoral education but not student passivity. ${ }^{126}$

Doctoral programs that attend to the multiple domains of a scholar's identity within healthy intellectual communities recognize that, while doctoral education is only one point on an individual's life trajectory, it represents the formative period for an aspiring scholar. ${ }^{127}$ While the particulars of such programs would be faculty-specific, programs designed on this model would be necessarily experiential, not only helping students learn the skills and possibilities of a scholarly identity by engaging in them, but also providing doctoral students with opportunities to learn the law deeply in experiential ways, whether through designing a course, providing public legal education seminars, or participating in university governance. ${ }^{128}$ The common thread linking these programs would be the aspiration to help doctoral students become legal scholars who can, in the face of future uncertainty and complexity, ask the right questions, design strategies appropriate to answering them, identify the collaborative networks that should be called upon, assess the value of the results obtained, and innovate effectively and creatively. Such students of today would be wellplaced to lead the law faculties of tomorrow.

\section{CONCLUSION}

In this article, we have explored an issue that has been persistently forgotten from the discourse on the future of legal education, the role of graduate studies in law. We have argued that graduate legal education should no longer be forgotten. Not only are today's graduate students vital to how the law faculty will operate and educate in the future, but thinking about graduate studies is an opportunity for law faculties to reflect on, and be optimistic about, their institutional missions and the way in which legal education, both graduate and undergraduate, is provided today and in the future.

$123 \quad$ McAlpine \& Asghar, supra note 91 at 169; Golde et al, ibid at 59.

Golde et al, ibid at 59.

Ibid 60-61.

Ibid at 64.

Golde, supra note 57 at 64; Austin \& McDaniels, supra note 24 at 51.

Austin, "Bridge," supra note 98 at 124, 138-39; McAlpine \& Asghar, supra note 91 at 175; Macdonald, "Everyday Lessons," supra note 1 at 3; Austin \& McDaniels, supra note 24 at 53. On the rise of experiential legal education and the merits of this evolution, see Lorne Sossin, "Experience the Future of Legal Education” (2014) 51:4 Alta L Rev 849. 
Forgetting graduate studies from the discourse perpetuates inaccurate distinctions in legal education generally and ignores the present and future reality of graduate studies in law. This absence is linked to assumptions that we propose be rethought about the purpose of legal education and the nature of the law faculty. Legal educators should aspire to cultivate jurists, and law faculties should be understood as holistic institutions, educating students, at all levels of study, to be stewards of the discipline of law. In these revised assumptions, we find the basis of an understanding of the law faculty and of graduate studies that is more hopeful about the future of legal education than the current discourse of crisis. 